\title{
The Validity of Athletic Sports Models for Elementary School Students To Improve Gross Motor Skills and Self-Concept
}

\author{
*Rifki Nanda Putra, Bafirman \\ Faculty of Sport Science \\ State, University of Padang \\ Padang, Indonesia \\ rifkinp25@gmail.com
}

\author{
Fuaddi \\ Faculty of Sport Science \\ State, University of Yogyakarta \\ Yogyakarta, Indonesia
}

\begin{abstract}
The purpose of this study was to examine the validity of athletic sports models for children to improve gross motor skills in elementary school students. The method used is the evaluation of research subject documents. The subject of this study was a document on the athletic learning model for children with two leading indicators, namely gross motor skills and self-concept. Data collection techniques in this study were used the Delphi technique from 3 experts. Data analysis techniques used the Guilford model. While collecting data for empirical validity was using field tests with 20 students. Besides, data were analyzed using product moment statistics with the SPSS 23 series application. The results show the kid's athletics model to improve gross motor skills, and self-concept shows the results of the validity of a valid category.
\end{abstract}

Keywords-Validity, Kids Athletics, Gross motor skills, self-concept

\section{INTRODUCTION}

Physical Education, Sports and Health (PJOK) should start at an early age to stimulate the formation of organic, motor, intellectual and emotional development. "PE provides opportunities for students to be directly involved in a variety of learning experiences through movement activities carried out systematically, directed and planned. "States that physical education is a medium to encourage the development of motor skills, physical abilities, knowledge, and reason"[1]. The appreciation of values likes attitude, mental, emotional, and social). The structure and curriculum of physical education in elementary schools currently have characteristics that consist of basic technical skills in sports. The basic technical skills of this sport will be mastered if previously mastered basic movement skills. One branch of the sport is Athletics. "Athletic learning is appropriate if it is introduced to students since elementary school. Besides that, with students learning athletics, indirectly the students' basic mobility skills will also increase, these abilities include loco motor, non-loco motor and manipulative abilities"[2]. This basic mobility ability is useful for preparing students to more easily master the advanced complex mobility so that the success of an athletic learning is determined by the basic mobility abilities they master.

Therefore, children's education through basic movements needs to provide various activities that can develop various aspects of the child's potential development or ability. "One of the potentials or abilities of children that needs to be improved is gross motor skills. Gross motor skills are movements or body movements that use large muscles as the main basis movement"[3]. Another case according "explains the ability of gross motor as a control of body movements through coordinated activities between the nervous system, muscles, brain and spinal cord, namely the women needed since the age of toddlers as part of the growth and development of children"[4]. Correspondingly, "gross motor is a body movement that uses large muscles in the body and all members of the body that are affected by self-maturity"[5]. Through motor learning in elementary school will affect several aspects of students' lives such as: "1) through motor learning children get entertainment and get pleasure, 2) through motor learning children can move from weak conditions to independent conditions, 3) through motor learning children can adapting to the environment, 4) through motor learning will support the child's ability in various ways, and 5) through motor learning will encourage children to be independent so that they can solve the problems they face" [6]. To improve gross motor skills done early because at this time, the most appropriate time to learn children's gross motor skills. The body will be more flexible than the adult body so that children are easier to carry out activities aimed at developing gross motor skills and potential.

"The development of one's potential will not be realized if it is not pursued. One's effort to actualize his potential will also shape his attitude and personality" [7]. The most important thing is that actualization of potential can be obtained if someone has a self-concept. "The concept of self is the basis of the child's part to decide whether he will hate himself or will love himself" [8]. The concept of self is the main foundation for the success of the learning process, including how a person learns to improve his emotional intelligence, in line with the opinion of Brooks in "self-concept as a perception of the individual himself, both physical, social and psychological nature obtained through experience from individual interactions with others"[9] So the concept of self includes various aspects of development in a person, including cognitive, social, and emotional aspects.

Based on introduction studies in 004 Rokan IV Koto State Elementary School. Seeing the movements that stimulate the gross motor development of children does not 
match the characteristics of the movements performed by students. Students tend to be lazy to exercise and are easily drowsy allegedly due to teacher weaknesses in the implementation of less varied learning movements as required by students in elementary schools. As a result students are lazy to move so that the impact of low gross motor skills and self-concept students. Seeing the existing description, the objective of physical education will be difficult to achieve and will lead to ineffective and inefficient work, whereas actually in the physical education learning process, the teacher is able to apply the right model for physical education that can support motor development and self-concept. The physical education process will succeed, if the learning methods and models are in accordance with the curriculum applied and the characteristics of the child's motor skills. it means that the teacher must know the ability, enjoyment, needs of the child for movement and PJOK teachers in elementary school must be able to apply appropriate learning models and in accordance with the level of growth and development in improving students' gross motor skills and helping students to use their bodies more efficiently.

It means that the teacher must know the ability, enjoyment, needs of the child for movement and PJOK teachers in elementary school must be able to apply appropriate learning models and in accordance with the level of growth and development in improving students' gross motor skills and helping students to use their bodies more efficiently. Addressing the existing problems, it is necessary to find an appropriate learning model to overcome the problem of lack of gross motor skills and self-concept, one of the learning models is through the Kids' Athletics model of gross motor skills and selfconcept for fourth grade students of elementary schools. The purpose of writing this article is to test the validity of the contents of the kids' athletics learning model for gross motor skills and self-concept. The validity criteria of a product are based on the results of the content validity and construction validity. In the product developed an instrument was arranged. This validation instrument is in the form of a questionnaire addressed to experts. The questionnaire contains a list of statements accompanied by a scale of values used to provide an assessment on the draft development of the Kids Athletic model. This sheet uses a Linkert scale, with the measured Linkert scale the variable being translated into indicator variables, and the variable is used as a starting point for compiling instrument items which can be questions or statements. Furthermore, the instruments that have been prepared must be examined to determine the appropriateness of the assessment instruments based on the validity of their contents. Furthermore, using empirical validity test to see how valid the instrument after testing.

\section{RESEARCH METHODS}

This research use evaluation research. The subject of this research is a document model of Kids athletics learning in children with 2 main indicators, namely gross motor skills and self-concept. Data collection techniques use Delphi technique from 3 experts. Data analysis techniques use the Guilford model.

$$
P=\frac{f}{N} \times 100 \%
$$

$\mathrm{P}=$ Rate / percentage rate

$\mathrm{F}=$ frequency

$\mathrm{N}=$ sum of numbers

$100 \%=$ Constanta

Table .1 Validity Value Qualification

\begin{tabular}{lll}
\hline Percentage & Categories & Meaning \\
\hline $0 \%-20 \%$ & very less & Invalid \\
\hline $20.1 \%-40 \%$ & Less & Invalid' \\
\hline $40.1 \%-70 \%$ & Enough & Valid enough \\
\hline $70.1 \%-90 \%$ & Good & Valid \\
\hline $90.1 \%-100 \%$ & Very good & Very Valid \\
\hline
\end{tabular}

Source: [10]

\section{RESEARCH PROCEDURE}

The first step in drafting the kids athletics learning model for gross motor and self-concept, by (1) analyzing the performance or alternatives that have been undertaken by the physical education teacher (PE), (2) analyzing documents from research journals, textbooks about various domains needed in the preparation of learning models or performance appraisals and the results of needs analysis, (3) based on the analysis drafted instruments for kids athletics learning models to improve motor skills and selfconcept.

Second step. Evaluating the draft of the athletics learning model for kids' athletics by 3 experts who do not meet each expert is called the Delphi technique.

Third step. "Analyze quantitative and qualitative data. Quantitative data were analyzed using descriptive percentages using formulas" [11]. Qualitative data in the form of suggestions are reduced to be used to improve the language and content of a guide instrument for kids' athletics learning models to improve gross motor skills and game-based self-concepts in elementary school students.

Fourth step. Drafting and refining the draft guide for kids' athletics learning models to improve rough motor skills and self-concept based on elementary school students.

In addition, Empirical validation test is a follow-up test of the levels produced in the content validation test. In the empirical validity test, the subjects of the study were 20 students and also 2 assessors. For data processing techniques using product moment statistics with SPSS 23 series applications. As for the "product moment" formula from [17]. as follows:

$$
r_{x y}=\frac{N \Sigma x y_{-(\Sigma x)}(\Sigma y)}{\sqrt{\left(N \Sigma x^{2}-(\Sigma x)^{2}\left(N \Sigma y^{2}-(\Sigma y)^{2)}\right.\right.}}
$$


Explanation:

${ }^{\mathrm{r}} \mathrm{xy}=$ The correlation coefficient between variable $\mathrm{X}$ and $\mathrm{Y}$ variable
$\sum \mathrm{y}=$ Number of multiplications between variables $\mathrm{x}$ and $\mathrm{y}$
$\sum \mathrm{x}^{2}=$ The sum of the squares of the value $\mathrm{x}$
$\sum \mathrm{y}^{2}=$ The sum of the squares of the value $\mathrm{y}$
$\left(\sum \mathrm{x}^{2}\right)=$ The sum of $\mathrm{X}$ values squared
$\left(\sum \mathrm{y}^{2}\right)=$ The sum of $\mathrm{Y}$ values squared

\section{RESEARCH RESULT}

1. The results of the content validation test to improve gross motor and self-concept

Table 2. Results of the Guilford model analysis

\begin{tabular}{|c|c|c|c|c|c|c|}
\hline No & Part & Indicators & $\begin{array}{c}\text { No } \\
\text { Items }\end{array}$ & Sum & Persentage & Categories \\
\hline \multirow{13}{*}{1} & \multirow{13}{*}{ Material } & \multirow[t]{2}{*}{$\begin{array}{l}\text { Suitability with the } \\
\text { Elements in the } \\
\text { learning model }\end{array}$} & 1 & 8 & $80 \%$ & Valid \\
\hline & & & 2 & 9 & $90 \%$ & Valid \\
\hline & & \multirow[t]{2}{*}{$\begin{array}{c}\text { Compliance with } \\
\text { the curriculum }\end{array}$} & 3 & 8 & $80 \%$ & Valid \\
\hline & & & 4 & 8 & $80 \%$ & Valid \\
\hline & & \multirow{3}{*}{$\begin{array}{c}\text { Suitability with the } \\
\text { characteristics of } \\
\text { students }\end{array}$} & 5 & 9 & $90 \%$ & Valid \\
\hline & & & 6 & 9 & $90 \%$ & Valid \\
\hline & & & 7 & 9 & $90 \%$ & Valid \\
\hline & & \multirow{3}{*}{$\begin{array}{c}\text { Suitability with } \\
\text { learning } \\
\text { objectives }\end{array}$} & 8 & 7 & $70 \%$ & Valid enough \\
\hline & & & 9 & 8 & $80 \%$ & Valid \\
\hline & & & 10 & 9 & $90 \%$ & Valid \\
\hline & & \multirow{3}{*}{$\begin{array}{l}\text { Learning model } \\
\text { procedures }\end{array}$} & 11 & 9 & $90 \%$ & Valid \\
\hline & & & 12 & 8 & $80 \%$ & Valid \\
\hline & & & 13 & 8 & $80 \%$ & Valid \\
\hline \multirow{9}{*}{2} & \multirow{9}{*}{ Implementation } & \multirow{5}{*}{$\begin{array}{c}\text { Suitability with the } \\
\text { principles in the } \\
\text { implementation of } \\
\text { learning }\end{array}$} & 14 & 8 & $80 \%$ & Valid \\
\hline & & & 15 & 7 & $70 \%$ & Valid enough \\
\hline & & & 16 & 8 & $80 \%$ & Valid \\
\hline & & & 17 & 8 & $80 \%$ & Valid \\
\hline & & & 18 & 8 & $80 \%$ & Valid \\
\hline & & $\begin{array}{c}\text { Compliance with } \\
\text { the characteristics } \\
\text { of children's play }\end{array}$ & 19 & 8 & $80 \%$ & Valid \\
\hline & & \multirow[t]{3}{*}{$\begin{array}{c}\text { Setting children's } \\
\text { learning and } \\
\text { playing } \\
\text { environment }\end{array}$} & 20 & 8 & $80 \%$ & Valid \\
\hline & & & 21 & 9 & $90 \%$ & Valid \\
\hline & & & 22 & 9 & $90 \%$ & Valid \\
\hline 3 & Language & $\begin{array}{c}\text { Explanation of } \\
\text { Draft }\end{array}$ & 23 & 7 & $70 \%$ & Valid enough \\
\hline \multirow[t]{4}{*}{4} & \multirow[t]{2}{*}{ Formatting } & \multirow{2}{*}{$\begin{array}{c}\text { presentation of } \\
\text { appearance / } \\
\text { draft } \\
\end{array}$} & 24 & 8 & $80 \%$ & Valid \\
\hline & & & 25 & 7 & $70 \%$ & Valid enough \\
\hline & \multicolumn{2}{|c|}{ Total number } & & 202 & 2020 & \multirow{2}{*}{ Valid } \\
\hline & \multicolumn{2}{|c|}{ Average } & & 80,8 & 80,8 & \\
\hline
\end{tabular}

Based on table 2 above the percentage value of all indicators in the content domain shows $(83.9 \%=$ valid $)$ in the category $70.1 \%-90 \%$, it can be concluded that the content domain indicator items have high content validation [12]. Indicator items in the implementation domain show $(81.1 \%=$ valid $)$ in the category $70.1 \%$ $90 \%$, it can be concluded that the implementation domain indicators have high content validation [12]. Indicator items in the realm of language show $(70 \%=$ quite valid $)$ $40.1 \%-70 \%$, it can be concluded that the language indicator items have high content validation [12]. Indicator items in the domain of writing format show $(74 \%=$ valid $)$ $70.1 \%-90 \%$, it can be concluded that the items in the writing format domain have high content validation [12]. In other words all experts have a valid agreement for items that range in the range of $70.1 \%-90 \%$, and all items have a moderate's agreement for items ranging from $40.1 \%$ $70 \%$, thus it can be concluded that this instrument can be continued with the reliability test between raters.

Instrument construction results Guidelines for learning models for kids athletics to improve gross motor skills and self-concept after revision by experts as in table 3 , as follows

Table 3. Construction Instruments of the kids athletics learning model to improve gross motor skills and self-concept

\begin{tabular}{lll}
\hline No & Part & Indicators \\
\hline 1 & Materials & $\begin{array}{l}\text { Suitability with the Elements in } \\
\text { the learning model }\end{array}$ \\
\hline & & Compliance with the curriculum \\
\hline & $\begin{array}{l}\text { Suitability with } \\
\text { characteristics of students }\end{array}$ \\
\hline & $\begin{array}{l}\text { Suitability with } \\
\text { objectives }\end{array}$ \\
\hline & Learning model procedures \\
\hline 2 & Implementation & $\begin{array}{l}\text { Suitability with the principles in } \\
\text { the implementation of learning }\end{array}$ \\
\hline & & $\begin{array}{l}\text { Setting children's learning and } \\
\text { playing environment }\end{array}$ \\
\hline & & $\begin{array}{l}\text { Explanation of Draft } \\
\text { presentation of appearance / } \\
\text { draft }\end{array}$ \\
\hline 4 & Formatting &
\end{tabular}

\section{Empirical Validity Test Results of gross motor instruments}


Table 4. The results of the analysis of the empirical validity test of motor ability instruments

\begin{tabular}{|c|c|c|c|c|c|c|}
\hline & & 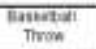 & isec Oash & Wal Pasn & 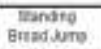 & Totastar \\
\hline \multirow[t]{3}{*}{ Bavietesil Thre } & Pearton Comebtom & 1 & $500^{\circ}$ & 327 & $523^{\prime}$ & $75 \%$ \\
\hline & So [etwed & & .025 & 100 & ant & 000 \\
\hline & h & ar & 20 & 10 & 20 & 20 \\
\hline \multirow[t]{3}{*}{ 45at Donn } & Faarson Comazion & $500^{\circ}$ & $T$ & .263 & 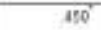 & 9101 \\
\hline & Bog (2-tansed & s2s & & 262 & ab & $\infty 000$ \\
\hline & N & 20 & 20 & 20 & 28 & 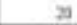 \\
\hline \multirow[t]{3}{*}{ Walfass } & Pearsen Comethen & $121^{\circ}$ & 203 & 1 & 248 & $.920^{n}$ \\
\hline & son cotand & ate & 252 & & 259 & $\omega$ \\
\hline & N & $2 \mathrm{n}$ & 20 & 20 & 20 & $n$ \\
\hline \multirow[t]{3}{*}{ 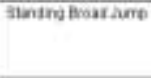 } & 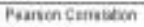 & 523 & $460^{\circ}$ & 268 & $T$ & 519' \\
\hline & so 12 -besd & giv & sat & .253 & & 022 \\
\hline & H & 30 & 30 & 20 & 20 & 20 \\
\hline \multirow[t]{3}{*}{ Toeds Sor } & Farson Combiation & $593^{4}$ & 910 & $\omega^{2}$ & $900^{\circ}$ & 1 \\
\hline & 80 costed & ate & ato & 103 & 022 & \\
\hline & tij & 10 & 20 & 20 & 26 & 20 \\
\hline
\end{tabular}

Table 4 above shows the count for a basketball throw of 0.753 , the count for a $4 \mathrm{sec}$ dash item is 0.910 , the count for a wall pass item is 0.630 , and the count for a standing broad jump item is 0.510 with a sample size of $\mathrm{N}=20$ students. The $\mathrm{r}$ value for $\mathrm{N}=20$ is 0.3783 . These results indicate that the count of all items is stated to be greater than rtable $=0.3061$. Based on the basis of decision making in correlation analysis it can be concluded that there is a significant relationship or correlation between basketball throw items, $4 \mathrm{sec}$ dash, wall pass and standing broad jump with total scores. Thus, it can be concluded that the motor skills are valid.

\section{Empirical Instrument Validity Test Results Self- concept}

Table 5. The results of the analysis of the validity of the Self Concept instrument test

\begin{tabular}{|c|c|c|c|c|c|}
\hline \multicolumn{6}{|c|}{ Correlations } \\
\hline & & Crra Tubuh & Harga Diri & Peran & Total skor \\
\hline \multirow[t]{3}{*}{ Citra Tubuh } & Pearson Cocteiation & 1 & $.653^{\prime}$ & $451^{\circ}$ & $.800^{-17}$ \\
\hline & 819. (2-taileds & & 011 & .046 & 000 \\
\hline & $\mathrm{N}$ & 20 & 20 & 20 & 20 \\
\hline \multirow[t]{3}{*}{ Harga Din } & Pearson Cocrelation & $553^{\circ}$ & 1 & 355 & $.795^{\prime \prime}$ \\
\hline & Sig $\{2$-tailed $\}$ & D11 & & 125 & 000 \\
\hline & $\mathrm{N}$ & 20 & 20 & 20 & 20 \\
\hline \multirow[t]{3}{*}{ Peran } & Pearson Correlation & $451^{\circ}$ & 355 & 1 & $790^{\circ 1}$ \\
\hline & Sig. (2.tuited) & 046 & 125 & & 000 \\
\hline & N & 20 & 20 & 20 & 20 \\
\hline \multirow[t]{3}{*}{ Totai Shot } & Pearson Cocteiation & $.800^{27}$ & $.795^{\prime \prime}$ & $790^{17}$ & 1 \\
\hline & 81g (2-taileds) & 000 & .000 & .000 & \\
\hline & $\mathrm{N}$ & 20 & 20 & 20 & 20 \\
\hline
\end{tabular}

- Correlaton is significant at the 0.05 inwel (2-tailed)

- Correlaton is signifitant at vie 0.01 leves (2-tailed).

Table 5 above shows the count for body image is 0,800 , the count for self-esteem items is 0.795 , and the count for role items is 0.790 . with a sample size of $\mathrm{N}=20$ students. The $r$ value for $\mathrm{N}=20$ is 0.3783 . These results indicate that the count of all items is stated to be greater than rtable $=0.3061$. Based on the basis of decision making in correlation analysis it can be concluded that there is a significant relationship or correlation between the body's image system, self-esteem and the role of the total score. Thus it can be concluded that the self-concept items are valid.

\section{DISCUSSION}

The results of this study indicate that the kids' athletics learning model instrument to improve gross motor skills and self-concept has been agreed by experts to have high validity. The results of this study are consistent with the opinion "which states that the right instrument used to measure must have high content validation"[13]. According to "states that the requirement of the assessment instrument should have high enough content validation"[14]. Content validation provides evidence of the extent to "which the elements of the instrument are relevant and represent the constructs that are targeted for specific assessment purposes"[15]. "States the content validity shows the ability of selected items reflects indicators of construct variables in the measurement"[16].

Furthermore, if the instrument does not have content validation, it is impossible to show the reliability of the instrument. After the content validation is found, then the kids athletics learning model instrument to improve motor skills and self-concept needs to look for empirical validation. In the empirical validity test, the count of all items shows the results that are greater than the table, from these results it can be concluded that all indicators on the item used are declared valid.

\section{CONCLUSION}

Based on the results and discussion it can be concluded that the assessment instrument items must provide evidence that the instrument is relevant and represents the targeted construct. In addition, the way to prove it is to do content validation and continue with empirical validation of the developed model. From the results of the analysis of the data presented in the previous point, it can be concluded that all the systems of motor ability and selfconcept taken in the instruments of the kids athletics learning model are relevant and represent what they want to be assessed with evidence of a high level of validity both in the validity test content as well as on empirical validity tests or field trials.

\section{REFERENCES}

[1] Rosdiani, Dini, "Model Pembelajaran Langsung Dalam Pendidikan Jasmani dan Kesehatan," Bandung; Alfabeta. 2012

[2] Purmono Eddy, "Pedoman Mengajar Atletik," Yogyakarta; FIK UNY. 2017

[3] Rahyubi, ami, "Teori-teori Belajar Dan Aplikasi Pembelajaran Motorik," Majalengka, References. 2012.

[4] Hidayanti Maria, "Peningkatan Kemampuan Motorik Kasar Anak Melalui Permainan Bakiak," J. Pendidikan Usia Dini Vol. 7, 1 April. 2013.

[5] Dcaprio, Ricahard. 2013, "Aplikasi Teori Pembelajaran Motorik di Sekolah," Yogyakarta; Divapress. 2013, pp, 89-101. 
[6] Riyanto, Dkk, "Pengembangan Model Pembelajaran Keterampilan Motorik Berbasis Permainan Untuk Anak Sekolah Dasar Usia 9-10 Tahun,” J. Media Ilmu Keolahragaan Indonesia Vol. 6, Nomor. 1, Juni. 2016.

[7] Vera Vriskila S, "Pengaruh Pemberian Layanan Bimbingan Kelompok Terhadap Perkembangan Konsep Diri Siswa Kelas X SMA Negeri 1 Pariangan Kabupaten Humbang Hasundutan Tahun Ajaran 2011/2012 ," FIP; Universitas Negeri Medan. 2012

[8] Murdoko, E. W. H, "Personal Quality Managemen," Jakarta; PT Elax Media Komputindo. 2006.

[9] Masturah, Alifah Nabilah, "Gambaran konsep diri mahasiswa ditinjau dari perspektif budaya" J. ilmiah psikologi vol.2, No.2, Juni. 2017

[10] Martin Sudarmono, "Pengembangan Model Pembelajaran Sepakbola Gawang Ganda Bagi Siswa Smp N Ajibarang Kabupaten Bayumas Tahun Pelajaran 2009/2010," Universitas Negeri Semarang. 2010.

[11] Anas Sudijono, "Pengantar Statistic Pendidikan," Jakarta; PT. Raja Grafindo. 2006, pp 48-60.

[12] Tomoliyus, Sumaryanti, Herka Maya Jadmika, "Development of Validity and Reliability of Net Game Performance-Based Assessment on Elementary Students' Achievement in Physical
Education," J. of Assessment and Evaluation in Education. Vol. 6. Pp, 41-49. December 2016.

[13] Ghauri, P \& Gronhaug, K, "Research Methods In Business Studies, Harlow," FT; Prentice Hall. 2005

[14] Kevin Mercier \& Sarah Doolittle, “Assessing Student Achievement in Physical Education for Teacher Evaluation," J. of Physical Education, Recreation \& Dance. Vol 84:3, pp 38-42. December. 2013

[15] Almanasreh E, Rebekah Moles, Timothy F. Chen, "Evaluation of methods used for estimating content validity," Research in Social and Administrative Pharmacy https://doi.org/10.1016/j.sapharm.2018.03.066

[16] Newman I, Lim J, Pineda F, “Content validity using a mixed methods approach, Its application and development through the use of a table of specifications methodology," J. of Mixed Methods Research. Vol. 7(3), pp, 243-60. Jun. 2016.

[17] Sugiyono, "Metode Penelitian Kuantitatif, Kualitatif dan R\&D," Bandung; Afabeta. 2011 